\title{
Chronic Spinal Epidural Hematoma in an Adult
}

Mehmet Tokmak¹, Adem Bozkurt Aras², Inci Baltepe Altıok ${ }^{3}$ Mustafa Guven², Murat Cosar ${ }^{2}$

\section{ABSTRACT}

Spinal epidural hematoma (SEH) causing neurological deficit is a rare clinical entity. It may have either traumatic origin or it may occur spontaneously. Majority of the reported cases of SEH had nontraumatic causes and most of them were in the acute stage. Early chronic traumatic SEH in an adult is very rare and its prompt diagnosis with magnetic resonance imaging (MRI) is crucial for the accurate management of the patient. Our case was 56 year-old man presented at our neurosurgery clinic with a complaint of progressive burning pain, weakness, paresthesia over the left leg and hypoesthesia over the pelvic region. In this report, we presented a postraumatic lumbar SEH which is a unique presentation of chronic traumatic SEH because of long time interval between the trauma and beginning of the symptoms.

Key words: Chronic spinal epidural hematoma,lumbar,traumatic

\section{Bir Erişkinde Kronik Spinal Epidural Hematom \\ ÖZET}

Spinal epidural hematomda( SEH) nörolojik defisit nadir görülen bir klinik tablodur. SEH travmatik veya spontan nedenlere bağlı olușur. Literatürde SEH vakaları akut bașlangıçlı ve çoğunda spontan olarak ortaya çıktığı bildirilmiștir. Yetișkin hastalarda SEH nadir görülür. MRG hızlı tanısı konularak uygun tedavi yöntemi seçilmelidir. Bizim sunduğumuz olgu 56 yaşında erkeke hasta idi. Beyin cerrahi polikliniğimize ilerleyici yanma tarzında ağrı, pelvik bölgeden sol bacağa duğru uzanan duyu kaybı, yorgunluk ile başvurdu. Bu yazımızda travma ile semptomların ortaya çıkıșı arasında uzun süre olan bir olgu sunulmuştur.

Anahtar kelimeler: Kronik spinal epidural hematom, lomber, travmatik

\section{INTRODUCTION}

Spinal epidural hematoma (SEH) causing neurological deficit is a rare clinical entity. The first case was reported by Jackson et al. in 1869 . It accounts $1 \%$ of mass lesions in the spine (1). It may have either traumatic origin or it may occur spontaneously $(2,3)$. It may be associated with coagulation disorders, vascular malformations, neoplasms or pregnancy. Majority of the reported cases of SEH had nontraumatic causes and most of them were in the acute stage. SEH in an adult is very rare and its prompt diagnosis with MRI is crucial for the accurate management of the patient (2-4).

\section{CASE}

56 year-old man presented at our neurosurgery clinic with a complaint of progressive burning pain, weakness, paresthesia over the left leg and hypoesthesia over the pelvic region. He reported that he fell from $3 \mathrm{~m}$ height 6 month before admission. He didn't go any clinic at that time and his back pain resolved with some analgesics. There wasn't any history of outstanding disease or coagulation disorder. His vegetative functions were normal. On physical examination, straight-leg raising was limited and it was possible to 30 degree for the right leg. Sensation to fine touch was decreased on right S1 dermatome. There wasn't any Achille tendon reflex on the

\footnotetext{
${ }^{1}$ Istanbul Medipol University Faculty of Medicine, Department of Neurosurgery, Istanbul, ' ${ }^{2}$ anakkale 18 March University Faculty of Medicine, Department of Neurosurgery, Canakkale, 3Istanbul Medipol Hospital, Department of Radiology, Istanbul, Turkey
}

Correspondence: Adem Bozkurt Aras

Canakkale 18 March University, Faculty of Medicine,Department of Neurosurgery, Canakkale-Turkey

Fax: +90 2862635957 Phone: +90 5054785043

e-mail: adem_aras@yahoo.com 


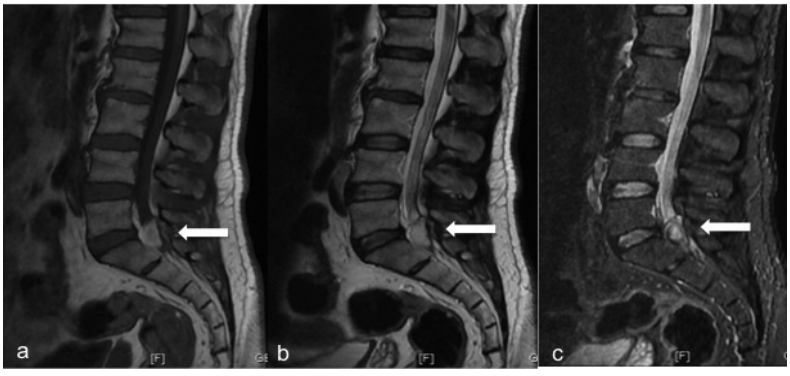

Figure 1. T1 (a), T2 (b) and STIR (c) sequences of thelumbar spine in sagittal plane shows hyperintense hematoma in the spinal canal at L5-S1 level.

right side. Motor power was about grade $4 / 5$ strength of ankle plantarflexion. Plain radiograph of lumbar spine sh line on CT scan. MRI of the lumbar region showed hyperintense epidural lesion on both $\mathrm{T} 1$ and $\mathrm{T} 2$ sequences at the level of $\mathrm{S} 1$ vertebra. Lesion was located at right half of the spinal canal and was compressing $\mathrm{S} 1$ root and dural sac severely. There was no signal loss on fatsuppressed sequences (Figure 1 and 2).

Laminectomy at L5 and S1 level was performed. The mass was severely adhered to dural sac and it was displacing the dural sac to left and anterior. Its wall thickness was $2 \mathrm{~mm}$ and its content was dark gray-black coloured fluid. There was vascularization on the wall. Hematoma is evacuated from epidural space and its wall was completely excized. After evacuation, dural sac and S1 root were totally free. No peroperative complication was happened. Histological findings revealed chronic hemorrhage, chronic inflammatory cell inflitration and hypocellular fibrous wall. There were no evidence of tumor, vascular malformation or infection. Excruciating pain in patient's right leg was absent after the operation. At the second day, he is discharged without any

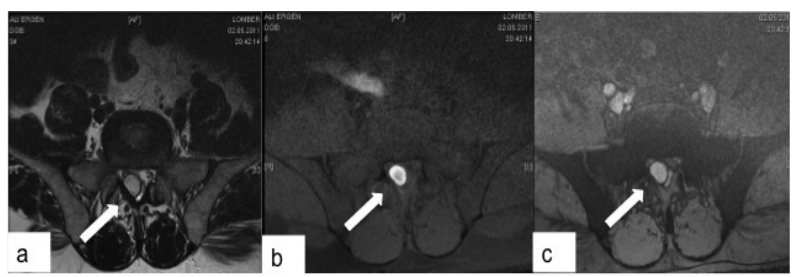

Figure 2. T2 (a), fat sat T1 (b) and gradient echo (c) sequences of the lumbar spine in axial plane shows hyperintense hematoma. Hypointense wall of the hematoma is seen in T2 weigthed and gradient echo sequences.

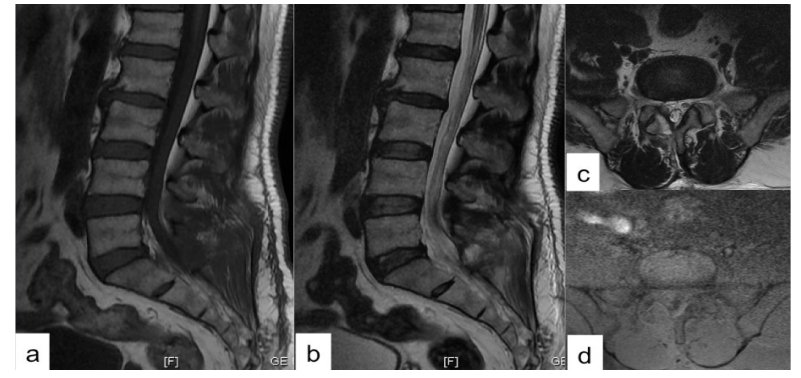

Figure 3. T1 (a) and T2 (b) sequences in sagittal plane, $T 2$ (c) and fat-sat T1 (d) sequences in axial plane shows no hematoma at L5-S1 level.

problem and he had full recovery at seventh day postoperatively. Nearly one month later after the operation, serial control MRI images showed no hematoma at L5-S1 level (Figure 3).

\section{DISCUSSION}

Spinal epidural hematoma causing neurological deficit is a rare clinical entity. It affects 1 per 1.000 .000 people annually (5). Male to female ratio is reported to be $1,5: 1$. It is mostly seen after forth or fifth decades of life $(6,7)$. However case reports seen in young age groups have rarely been reported in the literature (8).

Spinal epidural hematomas occur at the posterior surface of the spinal cord because of the anatomical course of the venous plexus(9). Groen and Ponssen reported in their studies that epidural hematomas are localized more frequently in posterior epidural regions. Spontaneous epidural hematoma is rarely observed in lumbar region, but frequently in thoracic region. Mahkam et al. found that five cases out of 49 spinal hematomas were in lumbar region(10). It has been considered spontaneous in most cases $(2,3)$. Spontaneous SEH may be associated with anticoagulation, thrombolysis, blood dyscrasias, coagulopathies, thrombocytopenia, neoplasms or vascular malformations. Traumatic causes of SEH reported in the literature are spinal manipulation therapy, obstetrical birth trauma, lumbar puncture, epidural anesthesia, missile injury, falls from height of 3 to 20 feet, motor vehicle accidents (3). Additionally spondylosis, rheumatoid arthritis, Paget's disease, ankylosing spondylitis are risk factors for traumatic SEH (2).

The pathophysiology of SEH is not clearly understood. It could arise from either an artery or vein. Some investi- 
gators suggest that the fragility of epidural venous plexus should increase bleeding tendency(9). The venous plexus in the epidural space is most commonly accepted source. Epidural venous plexus has thin valveless vessels so it may rupture with abrupt changes in venous pressure $(2,3)$. Clinical signs related to spinal epidural hematoma are numerous. Neurologic examination may be normal, or it can be presented with backache, lumbalgia, paresis or paraplegia(11). Symptoms secondary to posttraumatic SEH usually appear immediately after the inciting event, though rarely they have been observed presenting in a delayed fashion $(2,12)$. In our case, neurological symptoms started 5 months after the traumatic event and signal characteristics of the hematoma was compatible with the time interval. Hematoma in our case has a wall and the wall is hypointense in both $\mathrm{T} 1$ ve $\mathrm{T} 2$ sequences. This is a finding of early chronic hematoma (2). MRI is the modality of choice for the diagnosis of SEH. It can differentiate epidural hematoma from disc extrusions accurately because of the signal charasteristics of the hematoma. MRI has the advantage to do the investigation of spinal canal in all planes and its soft tissue resolution is perfect $(2,12)$.

Epidural hematomas can be distinguished from subdural hematomas by MRI. Epidural hematomas are viewed as biconvex on MRI. Epidural hematomas should be differentiated from epiduritis, neural cysts, metastatic tumors and vertebral $\operatorname{disc}(1,2)$. The long time interval between the time of trauma and the beginning of the symptoms might raise the question whether hematoma was a result of nontraumatic cause. Actually in our case there is no other explanation other than traumatic cause because he has no predisposing factors or history of any other conditon like strong valsalva maneuver $(5,13)$. The treatment should be initiated according to the results of neurological examination and radiological findings $(4,11)$. Some authors suggest emergency surgery, planning the surgery time according to the lesion's dimension and neurologic status(9). The following factors are not related to the type of postoperative therapy and prognosis of the disease; age and gender of patient, place of hematoma and size of lesion(9).

The treatment of choice is emergent surgical evacuation of hematoma with laminectomy. Preoperative neurological findings and timing of surgery from the onset of symptoms determine the surgical outcome $(10,14,15)$. Groen et al. evaluated 330 patients and reported that preoperative neurological findings are associated with postoperative status of the patients(10). According to some reports, clinical and radiological follow-up without surgical intervention can be a choice if neurological deficits are not prominent.

In patients presenting to emergency service with severe backache and lumbalgia, spinal epidural hematoma should be considered in differantial diagnosis of lumbar disc hernia despite the absence of any neurological findings. After literature review, our case demonstrates a unique presentation of chronic traumatic SEH because of long time interval between the trauma and beginning of the symptoms.

\section{REFERENCES}

1. Jackson R. A case of spinal of spinal apoplexy. Lancet, 1869;2:5-6

2. Holtas S, Heiling M, Lonntoft M. Spontaneous spinal epidural hematoma: findings at MR imaging and clinical correlation. Radiology 1996;199: 409-13

3. Lefranc F. Traumatic epidural hematoma of the cervical spine, MRI diagnosis and spontaneous resolution: Case report. Neurosurgery 1999;44: 408-10

4. Gundry $C R$, Heithoff KB. Epidural hematoma of the lumbar spine: 18 surgically confirmed cases. Radiology 1993;187: 427-31

5. Cuenca PJ, Tulley EB, Devita D, Stone A. Delayed traumatic spinal epidural hematoma with spontaneous resolution of symptoms. J Emergency Med 2004; 27(1):37-41

6. Chan DT, Boet R, Poon WS, Yap F, Chan YL. Spinal shock in spontaneous cervical spinal hematoma. Acta Neurochic ( Wien) 2004;146:1161-3

7. Chen CJ, Hsu WC. Imaging finding of spontaneous spinal epidural hematoma. J.Formos Med Assoc 1997;96:283-7

8. Guzel A, Simsek $O$, Karasalihoglu S, Kucukugurluoglu $Y$, Acunas B, Tosun A, et al. Spontaneous spinal epidural hematoma after seizure: A case report. Clinic Ped (Phila) ,2007.;46:263-5

9. Serdar A,Ibrahim BA, Omer A,Emre D: Spontaneous regression of traumatic lumbar epidural hametomas. Am J Case Rep 2012;13:258-61

10. Groen RJ, Ponssen $H$ : The spontaneous spinal epidural hematoma: a study of the etiology. J Neurol Sci 1990;98: 121-38

11. Lederle FA, Cundy KV, Farinha P, McCormick DP: Spinal epidural hematoma associated with warfarin therapy. Am J Med 1996;100: 237-8

12. Groen RJM, van Alphen HA. Operative treatment of spontaneous spinal epidural hematomas: a study of factors determining postoperative outcome. Neurosurgery 1996;39: 494-508

13. Gundağ M, Hakan M, Doğan K, Kıtıs S, Özkan N. 
Spontaneous resolution of paraparesisi because of acute spontaneous thoracolumbar epidural hematoma. Iran Red Crescent Med J 2012;14(9):574-7

14. Nagata K, Ariyoshi M, Ishibashi $K$ et al: Chronic lumbar epidural hematoma in a patient who had spondylolysis at the third lumbar vertebra: report of a rare case involving a seventeen-year-old adolescent. J Bone Joint Surg Am 1998;80: 1515-20
15. Chung $C L$, Jun YC, Yuk KL, Ping HL, Yuh TL. Spontaneous spinal epidural hematoma: A case report and review of the literatures. Acta Neurol Taiwan 2012;21:31-4 